\title{
Evaluation of in-vessel co-composting of yard waste and development of kinetic models for co-composting
}

\author{
K. M. Sangamithirai ${ }^{1} \cdot$ J. Jayapriya $^{1} \cdot$ J. Hema $^{2} \cdot$ Ravi Manoj $^{1}$
}

Received: 22 September 2014/Accepted: 8 April 2015/Published online: 13 August 2015

(C) The Author(s) 2015. This article is published with open access at Springerlink.com

\begin{abstract}
Background Organic solid waste management is a major challenge in high population density areas like apartments, educational institutions, hospitals, etc., as their disposal with other wastes could not only lead to issues like vector menace, odour generation but also would lead to loss of resources that could be reused such as nutrients which will benefit soil. In places like educational institutions, the major portion of waste generated is organic waste, especially food waste and yard waste from the campus, apart from paper waste. Composting is an organic waste treatment method that is cost effective and leads to resource recovery. In this study, the characteristics of composting of yard waste and co-composting of yard waste with wastes generated in an institution (university campuses of Anna University, Chennai, India) are examined. The composts were characterized in terms of total solids, volatile solids, $\mathrm{pH}$, electrical conductivity, carbon: nitrogen $(\mathrm{C}: \mathrm{N})$ ratio and total Kjeldahl nitrogen. The stability index and germination index of the compost were assessed.

Results The C:N ratio of all the different composts (except the one generated from yard with canteen waste consisting of vegetable waste) produced in this study has a value less than 30:1, which satisfies the basic requirements for the compost. It was also observed that the mature compost from these feedstocks did not have heavy metals at toxic levels.
\end{abstract}

J. Jayapriya

jayapriyachem@gmail.com

1 Department of Chemical Engineering, A. C. Tech, Anna University, Chennai 600 025, India

2 Department of Biotechnology, PSG College of Technology, Coimbatore 641604, India
Conclusion This study demonstrated that the co-composting of yard wastes with paper and canteen wastes (fruit, coffee grounds, tea leaf waste) could produce value-added products. In addition to that, kinetic models were developed to predict the decomposition rate constant of the process.

Keywords Composting - Yard waste - Paper waste · Canteen waste $\cdot$ Compost $\cdot$ Maturity

\section{Introduction}

Municipal solid waste (MSW), commonly known as trash or garbage, is defined as any waste generated by household, commercial and/or institutional activities. These municipal wastes are generally considered to be non-toxic and nonhazardous. There has been a significant increase in the generation of MSWs in India, as is the case around the world, over the last few decades as a result of rapid urbanization and rapid population growth (Diaz et al. 1993). It is known that high population density areas such as educational institutions, shopping malls and hospitals generate high volumes of MSW, which include a mixture of vegetable wastes in cooked and uncooked stages, leftovers, packaging materials, papers, plastics, rags, glass and other fabrics, dust, ash and a variety of combustible and non-combustible matter (Elwell et al. 1996). The current study was conducted in an educational institution with student strength of over 6000 in Anna University, Chennai, India. Canteens and hostels in the university generate vegetable and food wastes of approximately $350 \mathrm{~kg} / \mathrm{day}$. Apart from this, paper wastes and hardboards of $8000 \mathrm{~kg} / \mathrm{month}$ are also generated. These wastes are disposed along with other MSW, leading to not only pollution, 
odour generation, vector menace but also loss of valuable resources that could be recovered and reused. The efficient recovery of resources depends on source separation of organic, biodegradable waste and non-degradable waste. Nowadays, educational institutions, as is the case with many other places, focus on minimizing the amount of waste generated while maximizing the extraction of valueadded products from these wastes. The waste management hierarchy suggests resource recovery before waste disposal and an environmentally friendly one would be to reduce waste generation followed by reuse and composting rather than incineration or landfill (Giusti 2009).

Incineration of waste is a thermal process, which converts the waste materials into heat, gas, steam, and ash. However, due to the low calorific value of institutional generated waste, this process will not be efficient and cannot be exploited to recover energy completely from these wastes (Rand et al. 2000). Moreover, the incineration plants are not without their concerns, as they also lead to air pollution if not managed properly to reduce the polluting gases in the effluent. This could escalate the cost of the process and therefore may not be economically viable in developing countries. Composting involves the accelerated degradation of organic matter by microorganisms under controlled conditions (aeration, temperature and humidity), in which the organic material undergoes a characteristic thermophilic stage that allows sanitization of the waste by the elimination of pathogenic microorganisms (Lung et al. 2001).

There are various methods of composting from simple windrows to complex in-vessel composting (Misra and Roy 2003). In-vessel composting requires less space for operation than traditional outdoor windrow/pile composting methods. Further, In-vessel composting is not disrupted by weather changes. The final product compost could be used as soil conditioner and has the ability to increase soil porosity, structural stability, available water content and also reduces erosion (Sartori et al. 1985; Guidi et al. 1988; He et al. 1992; Hargreaves et al.2008; Diacono and Montemurro 2010). The process of composting and the quality of the final product is affected by several factors, including temperature, aeration, moisture content, etc., as well as substrate nature, especially $\mathrm{C} / \mathrm{N}$ ratio, particle size and nutrient content (Diaz et al. 2002; Jiang et al. 2011).

As the nature of waste generated from this place, mainly the food waste, paper waste and the yard waste is not expected to change with time and can be considered as representative sampling and its composting process analysis could be extended to similar situations elsewhere. The need for on-site rapid composting to reduce the space requirements demands that a controlled composting process is applied. In-vessel composting makes use of controlled conditions to augment the aerobic degradation process (American Planning Association, 2006; Renkow and Rubin 1998). In-vessel composters of various levels of sophistication are available based on proprietary technology. The current study aimed at the ascertaining the feasibility of subjecting yard waste generated in the campus to in-vessel composting and evaluate the effect of additives (food wastes and paper waste) in co-composting. The physiochemical and microbiological characterisation of the compost was done to evaluate its quality. The effect of changing various process parameters such as organic matter, temperature, moisture, $\mathrm{pH}$, electrical conductivity during the aerobic composting of institutional wastes, were used to develop kinetic models that could explain the composting rate.

\section{Materials and methods}

\section{Compost preparation}

Feedstock was collected from the different campuses of Anna University such as College of Engineering, Guindy, Chennai, India; Alagappa College of Technology, Chennai, India, and School of Architecture and Planning, Chennai, India. Sample collection included (1) yard wastes (dried fall leaves, grass clippings and wooden debris), (2) canteen wastes (fruit wastes, spent coffee grounds, spent tea leaves, vegetable waste) and (3) paper wastes. Three $\mathrm{kg}$ of feedstock in various combinations as described below was added into the composters (perforated cylindrical composter of $25 \mathrm{~cm}$ diameter and $80 \mathrm{~cm}$ height, made of plastic) daily for a period of 5 days. The process was carried out in three replicates in parallel. The experiments were carried out during the months of December 2011 to March 2012. The feedstock combinations were:

- Yard wastes (dried fall leaves: grass clippings: wooden debris, 1:1:1), (CY).

- Yard wastes + vegetable waste (2:1), (CYV).

- Yard wastes + fruit wastes (2:1), (CYF).

- Yard wastes + spent coffee grounds (2:1), (CYCo).

- Yard wastes + spent tea leaves (2:1), (CYT).

- Yard wastes + paper waste (2:1), (CYP).

The composts were manually turned over twice a week throughout the composting period of 3 months to control the temperature rise and provide proper aeration. The compost temperature was monitored at different compost depths using glass thermometers. Adequate moisture level was maintained by sprinkling water over the compost. The moisture level was maintained using the squeeze test (Solvita 2009). 


\section{Physicochemical analysis}

The chemical compositions of various raw materials used for the composting are given in Table 1. The $\mathrm{pH}$ and electrical conductivity were determined in compost-water extracts $(1: 10 \mathrm{w} / \mathrm{v})$ (Rhoades 1982). Moisture content (MC) was determined as weight loss upon drying at $105{ }^{\circ} \mathrm{C}$ in an oven for $24 \mathrm{~h}$. The Volatile solids (VS) were obtained by igniting the dried samples at $500{ }^{\circ} \mathrm{C}$ for $20 \mathrm{~min}$ [American Public Health Association (APHA) Standard Methods, 1992]. Total organic carbon (TOC) of compost was determined by Walkley-Black method (Nelson and Sommers 1982). Total-N was determined by the Kjeldahl method following digestion in salicylic acid with metal catalysts (Mulvaney 1996).

Phosphorus was analyzed by ammonium molybdateascorbic acid after acidification of the extracts with $4.5 \mathrm{M}$ $\mathrm{H}_{2} \mathrm{SO}_{4}$ as described by Murphy and Riley (1962) and Joergensen and Mueller (1996). The heavy metal content in the composts was determined after being digested in a solution of $\mathrm{HNO}_{3} / \mathrm{HCl}, 1: 3(\mathrm{v} / \mathrm{v})$ by Atomic Absorption Spectroscopy (AAS).

\section{Compost analysis}

The maturity and stability of the compost generated was analysed by germination index and $\mathrm{CO}_{2}$ evolution index, respectively. The germination index (GI) was calculated using seeds of Cucumber Himangi (Zucconi et al. 1981). The filter paper placed on glass Petri dishes with six seeds of cucumber was wetted with $10 \mathrm{ml}$ of a compost-water extract $(1: 10 \mathrm{v} / \mathrm{v})$.The Petri dishes were sealed to minimize the water loss and kept in the dark at room temperature. At the end of 5 days, the percentage of seed germination in the compost extract was compared with that of water-control.

The stability index was evaluated according to the $\mathrm{CO}_{2}$ evolution rate $(Q)$, in $\mathrm{mg} \mathrm{CO}_{2} \mathrm{~g}^{-1}$ compost day ${ }^{-1}$. The compost is considered as being very stable $(Q<2)$; stable $(Q<4)$; or unstable $(Q>4)$ (United States Department of Agriculture and the United States Composting Council-
Test Methods for Examination of Composting and Compost 2001). The moisture of the samples was adjusted to $70-85 \%$ and the samples were pre-incubated at room temperature for $24 \mathrm{~h} .5 \mathrm{~g}$ of the pre-incubated sample were transferred into an incubation vessel containing $20 \mathrm{ml}$ of $1 \mathrm{M} \mathrm{NaOH}$. The vessel was sealed and kept at $37{ }^{\circ} \mathrm{C}$ for 4 days. The amount of $\mathrm{CO}_{2}$ absorbed by $\mathrm{NaOH}$ was determined by back titration of the residual $\mathrm{NaOH}$ with $1 \mathrm{~N} \mathrm{HCl}$ using phenolphthalein as the indicator.

Total viable count (TVC) of bacteria in the compost was determined by plating diluted (1:10 dilution) suspension on nutrient agar, incubated at $32{ }^{\circ} \mathrm{C}$ and colonies counted. The analysis was done in triplicate.

\section{Kinetic models of composting}

The degradation of organic matter as a function of time follows first-order kinetics (Haung 1993; Hamoda et al. 1998; USEPA 2000).

$\mathrm{d} \frac{(O M)}{\mathrm{d} t}=-k_{t} \mathrm{~d} t$

where OM is the amount of biodegradable volatile solids at ' $t$ ' during the composting process and $k_{t}$ is the decomposition rate constant. In this study eight models were used to predict the decomposition rate constant. Two statistical parameters, namely reduced Chi-square value $\left(\chi^{2}\right)$ and Root Mean Square value (RMSE) were used to evaluate the goodness of fit of the developed models. Reduced Chisquare is the mean square of the deviations between the experimental and calculated values for the models and is used to determine the goodness of the fit. The lower the values of the $\chi^{2}$, the better the goodness of the fit (Pangavhane et al. 1999). The RMSE gives the deviation between the predicted and experimental values and it tends to zero for ideal models. The modelling efficiency (EF) also shows the ability of the model to describe data and its highest value is 1 (Yaldiz et al. 2001). A high value of EF and a low value of RMSE are chosen as the criteria for goodness of fit.

Table 1 Physicochemical characteristics of compost feedstocks

\begin{tabular}{|c|c|c|c|c|c|c|c|c|}
\hline Feedstock & $\mathrm{pH}$ & $\begin{array}{l}\text { Electrical } \\
\text { conductivity } \\
(\mathrm{dS} / \mathrm{m})\end{array}$ & $\begin{array}{l}\text { Moisture } \\
\text { content }(\%)\end{array}$ & $\begin{array}{l}\text { Volatile } \\
\text { solids (\%) }\end{array}$ & $\begin{array}{l}\text { Total } \\
\text { solids }(\%)\end{array}$ & $\begin{array}{l}\text { Total organic } \\
\text { carbon }(\%)\end{array}$ & $\begin{array}{l}\text { Total nitrogen } \\
(\mathrm{mg} / \mathrm{g})\end{array}$ & Carbon:Nitrogen \\
\hline CY & $4.8 \pm 0.1$ & $6.5 \pm 0.2$ & $35.2 \pm 0.2$ & $73.1 \pm 0.3$ & $64.8 \pm 0.2$ & $42 \pm 0.8$ & $38.9 \pm 0.1$ & $10.8 \pm 0.1$ \\
\hline CYF & $5.8 \pm 0.2$ & $6.4 \pm 0.4$ & $49.1 \pm 0.1$ & $73.6 \pm 0.5$ & $50.9 \pm 0.1$ & $32.9 \pm 0.2$ & $21.6 \pm 0.5$ & $15.2 \pm 0.3$ \\
\hline CYCo & $4.2 \pm 0.4$ & $13.8 \pm 0.6$ & $35.8 \pm 0.6$ & $72.6 \pm 0.1$ & $64.2 \pm 0.6$ & $28.7 \pm 0.4$ & $12.6 \pm 0.7$ & $22.8 \pm 0.5$ \\
\hline CYT & $6.3 \pm 0.1$ & $9.8 \pm 0.1$ & $38.5 \pm 0.6$ & $75.2 \pm 0.4$ & $61.5 \pm 0.6$ & $35.7 \pm 0.3$ & $23.3 \pm 0.5$ & $15.3 \pm 0.3$ \\
\hline CYV & $6.1 \pm 0.0$ & $7.2 \pm 0.7$ & $48.5 \pm 0.1$ & $74.4 \pm 0.4$ & $51.5 \pm 0.1$ & $53.51 \pm 0.1$ & $24.4 \pm 0.6$ & $21.9 \pm 0.4$ \\
\hline CYP & $5.6 \pm 0.3$ & $6.9 \pm 0.5$ & $31.6 \pm 0.0$ & $88.1 \pm 0.2$ & $68.4 \pm 0.0$ & $56.0 \pm 0.0$ & $11.5 \pm 0.6$ & $48.7 \pm 0.5$ \\
\hline
\end{tabular}


$\mathrm{RMSE}=\sqrt{\frac{\sum_{i=1}^{n}\left(k_{\mathrm{pre}, i}-k_{\exp , i}\right)^{2}}{N}}$

where $k_{\exp }$ is the experimental decomposition rate, $k_{\text {exp,mean }}$ the mean value of experimental decomposition rate, $k_{\text {pre }}$ the predicted experimental decomposition rate

$$
\begin{aligned}
\chi^{2} & =\frac{\sum_{i=1}^{N}\left(k_{\mathrm{exp}, i}-k_{\mathrm{pre}, i}\right)^{2}}{N-n} \\
\mathrm{EF} & =\frac{\sum_{i=1}^{n}\left(k_{\mathrm{exp}, i}-k_{\text {exp }, \text { mean }}\right)^{2}-\sum_{i=1}^{n}\left(k_{\mathrm{pre}, i}-k_{\mathrm{exp}, i}\right)^{2}}{\sum_{i=1}^{n}\left(k_{\mathrm{exp}, i}-k_{\text {exp }, \text { mean }, i}\right)^{2}}
\end{aligned}
$$

where ' $N$ ' corresponds to the number of observations and ' $n$ ' refers to the number of constants in the model.

\section{Results and discussion}

\section{Physicochemical analysis}

Composting and co-composting of yard waste with canteen and paper wastes generated in the institution were carried out under aerobic conditions and six different composts were produced. The physicochemical characteristics of feedstocks are presented in Table 1. At the end of the composting process the $\mathrm{pH}$ of the composted mass increased. The shift in $\mathrm{pH}$ towards neutral during the composting process (Table 2) favours the growth of aerobic bacteria and it drives the composting process (Agendia et al. 1997). The increase in $\mathrm{pH}$ values was completely attributed to the production of ammonia, presumably from protein degradation in wastes (Haug 1993). The changes in temperature during the composting process were measured at regular intervals of $24 \mathrm{~h}$ and varied as shown in Fig. 1. Temperature evolution reflects the microbial activity during composting and it is a good indicator of the process performance. Three temperature phases were observed: (1) an initial mesophilic phase $\left(25-40{ }^{\circ} \mathrm{C}\right)$ and $(2)$ a thermophilic phase $\left(>40{ }^{\circ} \mathrm{C}\right)$ which lasted for 2-5 weeks and (3) a final mesophilic phase, that is the maturity (curing) phase was maintained for 7-10 weeks.

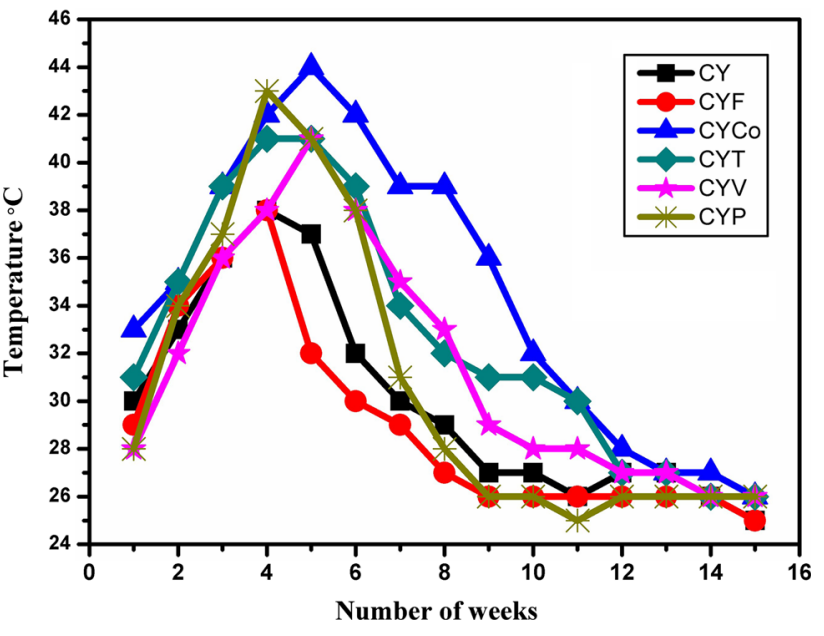

Fig. 1 Temperature changes in the in-vessel Composting process

Temperature rose from the first day of the process and became $40-44{ }^{\circ} \mathrm{C}$ on the 4 th week as a consequence of the rapid decomposition of organic matter and nitrogenous compounds by the action of microorganisms. As the organic matter became more stabilized and fewer nutrients were available, the growth rate of microorganisms slowed down and the temperature in the composting process gradually decreased to ambient temperature.

The electrical conductivity reflected the degree of salinity in the compost indicating its phytotoxic/phyto-inhibitory effects on the growth of a plant, if applied to soil (Li et al. 2008). In this study, a gradual increase in EC was observed for the various composting combinations and the increase lasted from 15 to 17 days (data not shown) and it is due to the organic matter degradation and release of different mineral salts in available forms (such as phosphate, ammonium, potassium) as reported by Garg et al. (2006). However, at the later stage of composting it was observed that the EC decreased for all the different composts produced (except CYV and CYP) (Table 2), indicating that the mineral salts could have been precipitated. These results are in agreement with findings previously reported by Wong et al. (1995). In general, the acceptable level of EC in compost is a value lower than $4 \mathrm{dS} / \mathrm{m}$ since

Table 2 Physicochemical characteristics of different composts

\begin{tabular}{lrlrlrlcc}
\hline Feedstock & $\mathrm{pH}$ & $\begin{array}{l}\text { Electrical } \\
\text { conductivity } \\
(\mathrm{dS} / \mathrm{m})\end{array}$ & $\begin{array}{l}\text { Moisture } \\
\text { content }(\%)\end{array}$ & $\begin{array}{l}\text { Volatile } \\
\text { solids }(\%)\end{array}$ & $\begin{array}{l}\text { Total solids } \\
(\%)\end{array}$ & $\begin{array}{l}\text { Total organic } \\
\text { carbon }(\%)\end{array}$ & $\begin{array}{l}\text { Total nitrogen } \\
(\mathrm{mg} / \mathrm{g})\end{array}$ & $\begin{array}{l}\text { Carbon:Nitrogen } \\
\text { ( }\end{array}$ \\
\hline $\mathrm{CY}$ & $7.4 \pm 0.2$ & $5.9 \pm 0.5$ & $49.8 \pm 0.2$ & $66.5 \pm 0.2$ & $50.2 \pm 0.2$ & $18.5 \pm 2.0$ & $17.2 \pm 0.1$ & $10.7 \pm 1.6$ \\
$\mathrm{CYF}$ & $7.6 \pm 0.1$ & $4.9 \pm 1.5$ & $59.5 \pm 0.4$ & $64.3 \pm 0.1$ & $40.5 \pm 0.4$ & $22.1 \pm 2.5$ & $19.9 \pm 1.1$ & $11.10 \pm 2$ \\
$\mathrm{CYCo}$ & $6.5 \pm 0.1$ & $6.7 \pm 0.8$ & $59.9 \pm 0.1$ & $62.3 \pm 0.7$ & $40.04 \pm 0.1$ & $6.37 \pm 4.0$ & $3.76 \pm 0.3$ & $16.9 \pm 3.1$ \\
$\mathrm{CYT}$ & $6.4 \pm 0.0$ & $7.2 \pm 0.2$ & $63.14 \pm 0.1$ & $67.8 \pm 0.5$ & $36.8 \pm 0.1$ & $26.7 \pm 3.4$ & $29.4 \pm 1.2$ & $9.1 \pm 2.3$ \\
$\mathrm{CYV}$ & $7.2 \pm 0.1$ & $9 \pm 0.5$ & $60.1 \pm 0.3$ & $65.2 \pm 0.4$ & $39.9 \pm 0.3$ & $40.5 \pm 0.7$ & $20.4 \pm 0.4$ & $19.8 \pm 0.4$ \\
$\mathrm{CYP}$ & $6.1 \pm 0.1$ & $8.1 \pm 1.1$ & $58.6 \pm 0.2$ & $80.6 \pm 0.6$ & $41.4 \pm 0.2$ & $45.7 \pm 3.1$ & $9.67 \pm 0.7$ & $47.2 \pm 2.8$ \\
\hline
\end{tabular}


otherwise it inhibits plant germination and growth (Rao Bhamidimarri and Pandey 1996). Since EC was high in all types of composts produced from university generated wastes, we need to dilute the produced compost before it can serve the purpose of a soil amendment. The water extracts of the compost was used for the germination assays in this study to overcome this effect.

The Total Organic Carbon in the composts was analysed at the end of the curing phase of composting and given in Table 2. Maximum TOC reduction in the composts compared to the respective feedstocks was observed for the feedstock combination CYCo $(78 \%$ reduction in TOC compared to the starting material). This might be due to the higher content of easily degradable organic matter in CYCo (C/N: 22.8), such as proteins, cellulose, and hemicellulose which are utilized by microorganisms as $\mathrm{C}$ and $\mathrm{N}$ sources. The TOC and TKN of the composts produced from different feedstock combination varies and so does their $\mathrm{C}: \mathrm{N}$ ratios. After 2 weeks, it was observed that the volatile solids were reduced by $10-12 \%$ in the matured composts compared to the respective feedstocks (Table 2).

From Table 2, a loss of TKN in compost was observed when compared to the feedstocks except for CYT. Further, these results showed that a TKN loss $(70 \%)$ was highest for CYCo when compared to CY. This could be attributed to the immobilization of $\mathrm{NH}^{4+}$ ions by the waste coffee grounds that possess high surface area and micropores.

\section{Compost stability and maturity}

Compost maturity and stability is analysed using $\mathrm{C} / \mathrm{N}$ ratio, stability index and seed germination index. Carbon to nitrogen ratio has been used as an indicator of the potential of compost stability. A mature compost should have an $\mathrm{C} / \mathrm{N}$ ratio $\leq 25$ (Woods End Research Laboratory 2005). Results showed that there was no significant reduction in $\mathrm{C}: \mathrm{N}$ ratio for the feedstock $\mathrm{CY}$, however, the co-composting of yard with tea wastes (CYT) reduced the C:N by $41 \%$. In a similar trend, the reduction of $\mathrm{C}: \mathrm{N}$ ratio by 25-26\% was observed with additives of fruit and coffee waste from canteen (Table 2). Previous studies reported that compost that is not well-decomposed (immature compost) has high $\mathrm{C}: \mathrm{N}$ ratio (C:N > 30:1) (Saviozzi et al. 1987; Jimenez and Garcia 1989; Washington State University-Whatcom Extension Research Report 2010). If high $\mathrm{C}: \mathrm{N}$ composts are used as soil amendment, carbon compounds in such composts continue to break down once incorporated into the soil and microorganisms tend to utilize the nitrogen from the soil to assist in the process (Huang et al. 2004; Tsutsuki 2009) which leaves the root zone temporarily nitrogen-poor-thereby inversely inducing $N$-immobilization process (Joern and Brichford 2006).

The C:N ratio of all the different composts (except CYP) produced in this study have $\mathrm{C}: \mathrm{N}<25: 1$, which satisfies the basic requirements for compost. Another parameter, stability index has also been used for the evaluation of compost stability. This index based on $\mathrm{CO}_{2}$ evolution considers a compost to be stable if the index has a value lesser than $2 \mathrm{mg} \mathrm{CO}_{2} \mathrm{~g}^{-1}$ compost day ${ }^{-1}$ (Tani 2009). In this study, the respiration rate of different composts such as $\mathrm{CY}, \mathrm{CYF}, \mathrm{CYT}$, CYCo were lesser than $2 \mathrm{mg} \mathrm{CO} \mathrm{g} \mathrm{g}^{-1}$ compost day ${ }^{-1}$ (Table 3). This is in close agreement with the evaluation of composts by Wang et al. (2004), they found that composts with respiration rate less than $2 \mathrm{mg}$ $\mathrm{CO}_{2} \mathrm{~g}^{-1}$ compost day ${ }^{-1}$ were not phytotoxic to seedlings and would be considered stable. On the other hand, it was noted that composts, CYP and CYV have stability index higher than $2 \mathrm{mg} \mathrm{CO}_{2} \mathrm{~g}^{-1}$ compost day ${ }^{-1}$, indicating these composts have not yet been stabilized.

Germination index is used as an indicator of maturity and phytotoxicity. A GI of more than $80 \%$ indicates phytotoxic-free and mature compost (Wang et al. 2004). Figure 2 shows the effect of different dilutions of the compost extracts on the germination index of cucumber seeds. The GI data suggests that direct application of compost bio-wash without dilutions showed high level of toxicity in the case of CYV and CYP and this may be attributed to the high EC of the composts. Moreover, at the dilutions of 40 and $60 \%$ of almost all composts showed significant increase of cucumber shoot and root length. The high water holding capacity of produced composts CYT and CYP (Table 3) suggests that, it could be used as soil amendment for the plants which are less tolerant to droughts.

Synthetic fertilizers are typically high in nitrogen, phosphorous and potassium. However, the composts attained from yard waste co-composting were high in iron content (Table 4) when compared with other micronutrients. Compost is used to improve soil structure and plant nutrition (Tiquia and Tam. 1998). However, the presence of heavy metals in composts is the main cause of adverse effects on human health, transmitted through the food chain from the plants (Gigliotti et al. 1996) and it was essential to analyze the contents of heavy metal in composts. The

Table 3 Water holding capacity and stability index of the different composts

\begin{tabular}{llllrrr}
\hline Compost & CY & \multicolumn{1}{l}{ CYF } & \multicolumn{1}{l}{ CYCo } & CYT & CYV & CYP \\
\hline Water holding capacity (ml/100 g sample) & $67.8 \pm 1.2$ & $63.5 \pm 1.3$ & $68.9 \pm 1.5$ & $72.1 \pm 1.1$ & $59.7 \pm 2.0$ & $88.6 \pm 1.8$ \\
Stability index $\left(\mathrm{mg} \mathrm{CO}_{2} \mathrm{~g}^{-1}\right.$ compost day $\left.^{-1}\right)$ & $1.41 \pm 0.1$ & $2.4 \pm 1.2$ & $1.06 \pm 0.5$ & $1.14 \pm 0.3$ & $8.6 \pm 0.9$ & $7.3 \pm 0.4$ \\
\hline
\end{tabular}




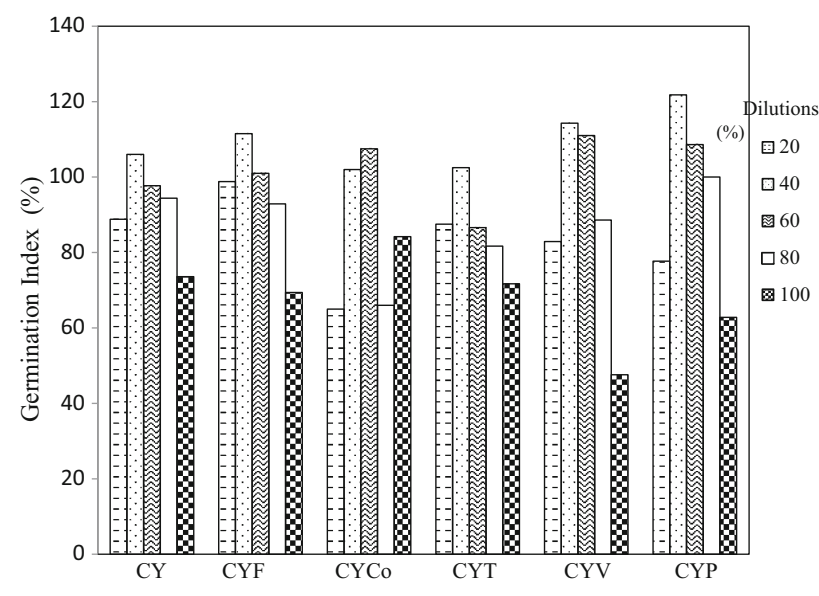

Fig. 2 Germination indexes of the different composts

heavy metal content $(\mathrm{Cd}, \mathrm{Cr}, \mathrm{Ag}, \mathrm{Cu}, \mathrm{Ni}, \mathrm{Pb}$ and $\mathrm{Zn})$ in the composts are shown in Table 5. It was clearly seen that heavy metal levels in the compost did not exceed the limits for application of compost as a soil amendment recommended by the USEPA (2000). Therefore, the mature compost from these feedstocks did not pose heavy metal toxicity issues.

\section{Bacterial growth on composts}

It was observed that the mesophilic bacterial density in CYF and CYCo compost $\left(23 \times 10^{6} \mathrm{CFU} / \mathrm{ml}\right.$; $\left.91 \times 10^{6} \mathrm{CFU} / \mathrm{ml}\right)$ was 10 -fold higher when compared with CY, CYT, CYV, CYP $\left(78 \times 10^{5}, 44 \times 10^{5}\right.$, $\left.67 \times 10^{5}, 48 \times 10^{5} \mathrm{CFU} / \mathrm{ml}\right)$ and they are equivalent to that found in fertile soils. The composts produced from institutional wastes possess good hygienic quality, since, pathogenic bacteria like, Escherichia coli and Salmonella dysenteriae were not detected in the matured compost.

\section{Kinetic models}

Proper design and operation of a composting reactor are prerequisites to compost quality and maturity. Hence, the kinetic models were developed to describe the relationship between composting rate and environmental factors over a range of practical interest. In this study eight models were used to predict the decomposition rate constant (Table 6). Models 1-3 were developed by Haung (1993) and Ekinci et al. (2001). Temperature and initial moisture content were mathematically considered in their developed models. However, different feedstocks which were tested in this study had distinct physico-chemical characteristics such as moisture, $\mathrm{pH}$ and $\mathrm{EC}$ in addition to $\mathrm{C}: \mathrm{N}$ ratio. Hence, it is expected that $\mathrm{pH}$ and $\mathrm{EC}$ may also influence the rate of composting. Kinetic models have developed in this study based on these attributes and it is given in Table 6 .

When the eight kinetic models were applied to the experimental results of in-vessel composting process, statistical analysis showed that the lowest RMSE value and

Table 4 Composition of micronutrients in the produced composts

\begin{tabular}{llllllll}
\hline Composts & Nitrogen $(\mathrm{mg} / \mathrm{g})$ & Phosphorus $(\mathrm{mg} / \mathrm{g})$ & Potassium $(\mathrm{mg} / \mathrm{g})$ & Iron $(\mathrm{mg} / \mathrm{g})$ & Magnesium $(\mathrm{mg} / \mathrm{g})$ & Calcium $(\mathrm{mg} / \mathrm{g})$ & Sodium $(\mathrm{mg} / \mathrm{g})$ \\
\hline $\mathrm{CY}$ & $17.2 \pm 0.1$ & $1.2 \pm 1.2$ & $1.05 \pm 0.3$ & $68.1 \pm 0.2$ & $1.11 \pm 1.2$ & $20.3 \pm 2.7$ & $0.63 \pm 1.5$ \\
$\mathrm{CYF}$ & $19.9 \pm 1.1$ & $1.72 \pm 2.2$ & $1.48 \pm 0.1$ & $46.4 \pm 1.1$ & $1.12 \pm 2.1$ & $33.6 \pm 1.6$ & $0.68 \pm 1.8$ \\
CYCo & $3.76 \pm 0.3$ & $1.78 \pm 1.8$ & $1.06 \pm 0.4$ & $68.9 \pm 2.1$ & $1.10 \pm 3.3$ & $12.2 \pm 1.2$ & $1.20 \pm 2.1$ \\
CYT & $29.4 \pm 1.2$ & $3.45 \pm 1.4$ & $1.08 \pm 0.2$ & $59.1 \pm 1.3$ & $1.09 \pm 1.8$ & $13.0 \pm 2.2$ & $0.84 \pm 0.8$ \\
CYV & $20.4 \pm 0.4$ & $1.80 \pm 3.1$ & $1.07 \pm 0.0$ & $47.9 \pm 0.1$ & $1.10 \pm 2.6$ & $11.2 \pm 2.8$ & $1.45 \pm 1.3$ \\
CYP & $9.67 \pm 0.7$ & $1.35 \pm 0.8$ & $1.01 \pm 0.1$ & $45.6 \pm 2.2$ & $1.09 \pm 2.0$ & $13.6 \pm 1.2$ & $0.92 \pm 0.9$ \\
\hline
\end{tabular}

Table 5 Heavy metal content in the produced composts

\begin{tabular}{|c|c|c|c|c|c|c|c|}
\hline Composts & $\begin{array}{l}\text { Cadmium } \\
(\mathrm{mg} / \mathrm{kg})\end{array}$ & $\begin{array}{l}\text { Chromium } \\
(\mathrm{mg} / \mathrm{kg})\end{array}$ & $\begin{array}{l}\text { Silver } \\
(\mathrm{mg} / \mathrm{kg})\end{array}$ & $\begin{array}{l}\text { Copper } \\
(\mathrm{mg} / \mathrm{kg})\end{array}$ & $\begin{array}{l}\text { Nickel } \\
(\mathrm{mg} / \mathrm{kg})\end{array}$ & $\begin{array}{l}\text { Lead } \\
(\mathrm{mg} / \mathrm{kg})\end{array}$ & $\begin{array}{l}\text { Zinc } \\
(\mathrm{mg} / \mathrm{kg})\end{array}$ \\
\hline $\mathrm{CY}$ & $3.57 \pm 1.1$ & $12.30 \pm 0.3$ & $3.8 \pm 0.1$ & $140 \pm 0.2$ & $7.8 \pm 0.3$ & $27.7 \pm 0.3$ & $887 \pm 0.1$ \\
\hline $\mathrm{CYF}$ & $1.1 \pm 0.6$ & $9.8 \pm 0.1$ & $3.1 \pm 0.1$ & $123.8 \pm 0.1$ & $4.7 \pm 0.2$ & $21.9 \pm 0.4$ & $886 \pm 0.2$ \\
\hline CYCo & $2.2 \pm 0.3$ & $20.3 \pm 0.2$ & $3.5 \pm 0.1$ & $88.5 \pm 0.6$ & $8.4 \pm 0.1$ & $24.5 \pm 0.2$ & $550 \pm 0.1$ \\
\hline CYT & $2.6 \pm 0.4$ & $21.6 \pm 0.1$ & $3.15 \pm 0.0$ & $67.7 \pm 0.5$ & $12.7 \pm 0.1$ & $37.5 \pm 0.3$ & $505 \pm 0.2$ \\
\hline CYV & $3.5 \pm 0.2$ & $11.8 \pm 0.3$ & $2.3 \pm 0.1$ & $46.7 \pm 0.2$ & $8.20 \pm 0.0$ & $23.6 \pm 0.1$ & $453 \pm 0.3$ \\
\hline CYP & $1.3 \pm 0.4$ & $50.9 \pm 0.1$ & $1.91 \pm 0.0$ & $18.3 \pm 0.6$ & $5.88 \pm 0.3$ & $34.9 \pm 0.0$ & $737 \pm 0.1$ \\
\hline $\begin{array}{l}\text { Recommended heavy metal } \\
\text { limits by USEPA }(\mathrm{mg} / \mathrm{kg})\end{array}$ & 35 & 1200 & 1100 & 1500 & 420 & 300 & 2800 \\
\hline
\end{tabular}


Table 6 Various kinetic models used in this study

\begin{tabular}{|c|c|c|}
\hline Sr. No. & Model & References \\
\hline 1. & $k_{T}=k_{20} a(T-20)$ & Haung (1993) \\
\hline 2. & $k_{T}=k_{23} a(T-23)$ & Kulcu and Yaldiz (2004) \\
\hline 3. & $k_{T}=a \exp \left(b\left[\left(\frac{m_{i}-c}{d}\right)+\left(\frac{T-e}{f}\right)\right]\right)$ & Ekinci et al. (2001) \\
\hline 4. & $k_{T}=a \exp \left(b\left[\left(\frac{m_{i}-c}{d}\right)+\left(\frac{T-e}{f}\right)\right]\right)-g \frac{E_{\mathrm{c}}}{T}$ & This study \\
\hline 5. & $k_{T}=a \exp \left(b\left[\left(\frac{m_{i}-c}{d}\right)+\left(\frac{T-e}{f}\right)\right]\right)\left(p_{\mathrm{H}}\right)^{\mathrm{h}}$ & This study \\
\hline 6. & $k_{T}=a^{(T-23)}\left(p_{\mathrm{H}}\right)^{b}(\mathrm{EC})^{c}$ & This study \\
\hline 7. & $k_{T}=\frac{a}{p_{\mathrm{H}}} \exp \left[\left(b T-\left(\frac{m_{i}-c}{d}\right)\right)\right]$ & This study \\
\hline 8. & $k_{T}=\left(p_{\mathrm{H}}\right)^{a} \exp \left(b\left[\left(\frac{m_{i}-c}{d}\right)+\left(\frac{T-e}{f}\right)\right]\right)-g \frac{E_{\mathrm{c}}}{T}$ & This study \\
\hline
\end{tabular}

Table 7 Applied kinetic models and results of statistical analyses

\begin{tabular}{|c|c|c|c|c|c|c|c|c|c|c|}
\hline Model No. & $a$ & $b$ & $c$ & $d$ & $e$ & $f$ & $g$ & RMSE & $\chi^{2}$ & $\mathrm{EF}$ \\
\hline 1 & 1.065 & $K_{20}=0.0006$ & - & - & - & - & - & 0.00014 & $2.03 \times 10^{-8}$ & 0.886 \\
\hline 2 & 1.065 & $K_{23}=0.0007$ & - & - & - & - & - & 0.00014 & $2.03 \times 10^{-8}$ & 0.889 \\
\hline 3 & 0.0001 & 0.06 & -46.2 & 5.47 & 10.7 & 0.99 & & 0.00011 & $1.99 \times 10^{-8}$ & 0.990 \\
\hline 4 & 0.0003 & 0.0025 & -35.02 & 0.22 & 15.9 & 0.04 & 1.23 & 0.00008 & $1.13 \times 10^{-8}$ & 0.995 \\
\hline 5 & 0.0005 & -0.054 & 51.65 & -9.9 & 36.9 & 15.1 & 0.66 & 0.0001 & $1.69 \times 10^{-8}$ & 0.992 \\
\hline 6 & 1.054 & -2.87 & -0.92 & - & - & - & - & 0.00031 & $1.12 \times 10^{-7}$ & 0.926 \\
\hline 7 & 0.0005 & 0.054 & -13.58 & -50.17 & - & - & - & 0.00014 & $2.35 \times 10^{-8}$ & 0.986 \\
\hline 8 & 0.900 & -0.043 & -33690 & 31890 & 153 & -0.64 & 0.93 & 0.00009 & $1.41 \times 10^{-8}$ & 0.993 \\
\hline
\end{tabular}

the highest EF values were found in model 4 (Table 7). According to the statistical results of the models, the best model to design the in-vessel composting process of university generated wastes as given below:

$k_{T}=\operatorname{aexp}\left(b\left[\left(\frac{m_{i}-c}{d}\right)+\left(\frac{T-e}{f}\right)\right]\right)-g \frac{E_{\mathrm{c}}}{T}$

In this model, ' $k_{T}$ ' is the decomposition rate constant (1/day), ' $m_{i}$ ' the initial moisture content (weight $\left.\%\right)$, ' $T$ ' the process temperature $\left({ }^{\circ} \mathrm{C}\right)$, ' $E_{\mathrm{c}}$ ' the electrical conductivity $(\mathrm{dS} / \mathrm{m})$ and $a, b, c, d, e, f$ and $g$ are empirical constants.

\section{Conclusions}

This study demonstrated that the co-composting of yard wastes with paper and canteen wastes produced value added products. The respiration rates of different composts such as CY, CYF, CYT, CYCo which were lesser than $2 \mathrm{mg} \mathrm{CO}_{2} \mathrm{~g}^{-1}$ compost day ${ }^{-1}$, suggests that they were not phytotoxic to seedlings and would be considered stable. Whereas, co-composting with paper and vegetable waste did not achieve maturity in the same duration. The high cellulosic content in paper waste which resulted in the high initial $\mathrm{C}: \mathrm{N}$ ratio and the presence of difficult to degrade (coconut husks, coir, peals, etc.) materials in the vegetable waste could be the reason for their slow composting. The dilutions of 40 and $60 \%$ of almost all composts showed significant increase of cucumber shoot and root length. The composts produced from different feedstocks had different levels of heavy metals, but it did not exceed the limits for application of compost as a soil amendment. The nature of soil determines what kind of nutrient amendments have to be added to it and this might indicate based on compost quality, which compost will be suited for a particular soil. Finally, the developed kinetic models for the composting process revealed that the in-vessel composting rates of the institutional wastes used in this study were best represented by a model as a function of temperature, electrical conductivity and initial moisture content.

Open Access This article is distributed under the terms of the Creative Commons Attribution 4.0 International License (http://crea tivecommons.org/licenses/by/4.0/), which permits unrestricted use, distribution, and reproduction in any medium, provided you give appropriate credit to the original author(s) and the source, provide a link to the Creative Commons license, and indicate if changes were made.

\section{References}

Agendia LP, KengneNoumsi YM, Fonkou T, Mefenya R, Sonwa JD (1997) Production of compost from biomass of Pistiastratiotes: 
treatment of domestic waste water in Yaoundé (Cameroon). Cah Agric 6:15-19

American Planning Association (2006) Planning and Urban design Standards. Wiley, New York

APHA (American Public Health Association) (1992) Standard Methods for the Examination of Water and Wastewater, APHA-AWWA-WEF, 18th edn

Diacono M, Montemurro F (2010) Long-term effects of organic amendments on soil fertility. A review. Agron Sustain Dev 30:401-422

Diaz LE, Savage GM, Eggerth LL, Golueke CG (1993) Composting and recycling municipal solid waste. Lewis Publisher, CRC. Press Inc., pp 160-162

Diaz MJ, Madejon E, Lopez F, Lopez R, Cabrera F (2002) Optimization of the rate vinasse/grape marc for co-composting process. Process Biochem 37:1143-1150

Ekinci K, Keener HM, Michael FC, Elwell DL (2001) Effects of temperature and initial moisture content on the composting rate of short paper fiber and broiler litter. ASAE Annual Meeting, California

Elwell DL, Keener HM, Hansen RC (1996) Controlled, high rate composting of mixtures of food residuals, yard trimmings and chicken manure. Compost Sci Util 4:6-15

Garg P, Gupta A, Satya S (2006) Vermicomposting of different types of waste using Eiseniafoetida: a comparative study. Biores Technol 97:391-395

Gigliotti G, Businelli D, Giusquiani PL (1996) Trace metals uptake and distribution in corn plants grown on a 6-year urban waste compost amended soil. Agr Ecosyst Environ. 58:199-206

Giusti L (2009) A review of waste management practices and their impact on human health. Waste Manage 29:2227-2239

Guidi G, Pera A, Giovannetti M, Poggio G, Bertoldi M (1988) Variations of soil structure and microbial population in a compost amended soil. Plant Soil 106:113-119

Hamoda MF, Qdais HAA, Newham J (1998) Evaluation of municipal solid waste composting. Resour Conserv Recycl 23:209-223

Hargreaves JC, Adl MS, Warman PR (2008) A review of the use of composted municipal solid waste in agriculture. Agric Ecosyst Environ 123:1-14

Haug RT (1993) The Practical Handbook of Compost Engineering. Lewis Publishers, Boca Raton

Haung RT (1993) The Practical Handbook of Compost Engineering. Lewis Publishers, Boca Raton

He XT, Traina SJ, Logan TJ (1992) Chemical properties of municipal solid waste composts. J Environ Qual 21:318-319

Huang GF, Wong JW, Wu QT, Nagar BB (2004) Effect of C/N on composting of pig manure with sawdust. Waste Manage 24:805-813

Jiang T, Schuchard F, Li G, Guo R, Zhao Y (2011) Effect of C/N ratio, aeration rate and moisture content on ammonia and greenhouse gas emission during the composting. J Environ Sci 23:1754-1760

Jimenez E, Garcia VP (1989) Evaluation of city refuse compost maturity: a review. Biol Waste 27:115-142

Joergensen RG, Mueller T (1996) The fumigation extraction method to estimate soil microbial biomass: calibration of the $\mathrm{k} E N$ value. Soil Biol Biochem 28:33-37

Joern BC, Brichford SL (2006) Calculating manure and manure nutrient application rates. Purdue Univ Coop Ext Serv Agron Guide 8:1-6

Kulcu R, Yaldiz O (2004) Determination of aeration rate and kinetics of composting some agricultural wastes. Bioresour Technol 93(1):49-57

Li XJ, Zhang RH, Pang YZ (2008) Characteristics of dairy manure composting with rice straw. Biores Technol 99:359-367

Lung AJ, Lin CM, Kim JM, Marshall MR, Nordstedt R, Thompson NP, Wei CI (2001) Destruction of Escherichia coli O157:H7 and
Salmonella enteritidis in cow manure composting. J Food Protect 64:1309-1314

Misra RV, Roy RN (2003) On-farm composting methods. Food and Agricultural Organisation of United Nations, Rome

Mulvaney RL (1996) Nitrogen-inorganic forms. In: Bigham JM et al (eds) Methods of soil analysis, part 3: chemical methods. Soil Science Society of America, Madison, p 1123

Murphy J, Riley JP (1962) A modified single solution method for the determination of phosphate in natural waters. Anal Chim Acta 27:31-36

Nelson DW, Sommers LE (1982) Total carbon, organic carbon, and organic matter. In: Page AL, Miller RH, Keeney DR (eds) Methods of soil analysis, part 2, second edn, Agron. Monogr. 9. ASA-CSSA-SSSA. Madison, pp 539-577

Ohtaki A, Sato N, Nakasaki K (1998) Biodegradation of polycaprolactone under controlled composting conditions. Polym Degrad Stabil 61:499-505

Pangavhane DR, Sawhney RL, Sarsavadia PN (1999) Effect of various dipping pretreatment on drying kinetics of Thompson seedless grapes. J Food Eng 39:211-216

Rand T, Haukohl J, Marxen U (2000) Municipal Solid Waste Incineration, A Decision Maker's Guide. The International Bank for Reconstruction and Development, World Bank, Washington, DC

RaoBhamidimarri SM, Pandey SP (1996) Aerobic thermophilic composting of piggery solid wastes. Water Sci Technol 33:89-94

Renkow M, Rubin AR (1998) Does municipal and solid waste composting make economic sense? J Environ Manage 53:339-347

Rhoades JD (1982) Soluble salts. In: Page AL, Miller RH, Keeney DR (eds) Methods of soil analysis, part 2, second edn, Agron. Monogr. 9. ASA-CSSA-SSSA. Madison, pp 167-180

Sartori G, Ferrari A, Pagliai M (1985) Changes in soil porosity and surface shrinkage in a remolded, saline clay soil treated with compost. Soil Sci 139:523-530

Saviozzi A, Riffaldi R, Levi-Minzi R (1987) Compost maturity by water extract analyses. In: De Bertoldi M, Ferranti MP, Hermite PL, Zucconi F (eds) Compost: production, quality and use. Elsevier, London

Senesi GS, Baldassarre G, Senesi N, Radina B (1999) Trace element inputs into soils by anthropogenic activities and implications for human health. Chemosphere 39:343-377

Solvita (2009) Official Solvita Guideline Compost Emissions TestV.6.0. Woods End Laboratories, Inc

Tani M (2009) Analysis of Total Carbon and Nitrogen in Composts and Manures. Obihiro University of Agriculture and Veterinary Medicine, Obihiro

Tiquia SM, Tam NFY (1998) Elimination of phytotoxicity during cocomposting of spent pig-manure sawdust litter and pig sludge. Biores Technol 65:43-45

Tsutsuki K (2009) Fundamentals in compost preparation and Utilization. Obihiro University of Agriculture and Veterinary Medicine, Obihiro

United States Department of Agriculture and the United States Composting Council (2001) Carbon dioxide evolution rate 05.08-B. In: Thompson WH (ed) Leege PB, Milner PD, Watson ME (co. eds) Test methods for examination of composting and compost. Jointly Published by the United States Department of Agriculture and the United States Composting Council. Accessed 05 August 2011

United States Environmental Protection Agency (USEPA) (2000) Biosolids technology fact sheet-in vessel composting of biosolids. EPA 832-F-00-061

Wang P, Changa CM, Watson ME, Dick WA, Chen Y, Hoitink HAJ (2004) Maturity indices for composted dairy and pig manures. Soil Biol Biochem 36:767-776 
Wong JWC, Li SWY, Wong MH (1995) Coal fly ash as a composting material for sewage sludge: effects on microbial activities. Environ Technol 16:527-537

Woods End Research Laboratory (WERL) (2005) Interpreting Waste and Compost Test. J Woods End Res Lab 2:1-10

WSU (Washington State University) (2010) Fundamentals of composting: why compost, materials and methods to ensure quality compost (Whatcom Extension Research Report). Washington State University, Washington

Yaldiz O, Ertekin C, Uzun HI (2001) Mathematical modelling of thin layer solar drying of seedless sultana grapes. Energy 26:457-465

Zucconi F, Pera A, Forte M, De Bertolli M (1981) Evaluating toxicity of immature compost. Biocycle 22:44-46 